\title{
ESTIMATION OF THE DYNAMIC ELASTIC PROPERTIES OF WOOD FROM Copaifera langsdorffii Desf USING RESONANCE ANALYSIS
}

Edson Rubens da Silva Leite', Paulo Ricardo Gherardi Hein², Tomé Moreira de Souza ${ }^{3}$, Giovanni Francisco Rabelo ${ }^{4}$

(received: March 18, 2010; accepted: October 28, 2011)

\begin{abstract}
Analysis of transverse vibrations has been identified as a simple, inexpensive, fast and effective method of characterizing the elastic properties of several materials, including wood. The objective of this study is to evaluate the dynamic elastic properties of wood from Copaifera langsdorffii through resonance analysis. A linear correlation was observed, with a coefficient of determination of 0.88 , between the dynamic modulus of elasticity $\left(\mathrm{E}_{\mathrm{d}}\right)$, as determined by BING (resonance analysis), and the static modulus of elasticity (E), as determined by a universal testing machine, for wood samples of Copaifera langsdorffii. A moderate correlation was observed (0.69) between the $\mathrm{E}_{\mathrm{d}}$ and the apparent density (D) of the samples. The shear modulus (G) was negatively correlated with $\mathrm{D}, \mathrm{E}$, and $\mathrm{E}_{\mathrm{d}}$, yet not significantly. The specific modulus, which is the stiffness to density ratio, was linearly correlated with the internal damping. This viscoelastic correlation is rarely reported in literature and indicates, for instance, wood quality for the manufacture of musical instruments. The BING system provided fast, reliable results for estimation of elastic properties, particularly stiffness, in wood of Copaifera langsdorffii.
\end{abstract}

Key words: Acoustic, transverse vibration, elasticity, shear, stiffness.

\section{ESTIMATIVA DAS PROPRIEDADES ELASTICO-DINÂMICAS DA MADEIRA DE Copaifera langsdorffii Desf POR ANÁLISE DE RESSONÂNCIA}

\begin{abstract}
RESUMO: A análise de vibrações transversais tem sido apontada como um método de baixo custo, simples, rápido e eficiente para caracterizar as propriedades elásticas de diversos materiais, incluindo a madeira. Neste trabalho, objetivou-se avaliar as propriedades elásticas dinâmicas da madeira de Copaifera langsdorffii por meio da análise de ressonância. Verificou-se uma correlação linear que apresentou coeficiente de determinação de 0,88 entre o módulo de elasticidade dinâmico $\left(E_{d}\right)$, determinado pelo BING (análise de ressonância) e o módulo de elasticidade estático (E), determinado por meio de uma máquina universal de ensaios para as amostras de lenho de Copaifera langsdorffii. Houve também correlação moderada $(0,69)$ entre o $E_{d}$ e a densidade aparente (D) das amostras. $O$ módulo de cisalhamento $(G)$ apresentou correlação negativa com a $D, E$ e $E_{d}$ porém de baixa magnitude. O módulo especifico, que é a relação entre a rigidez e a densidade da madeira, se correlacionou linearmente com o amortecimento interno. Essa relação viscoelástica é raramente relatada na literatura e indica, por exemplo, a qualidade da madeira para manufatura de instrumentos musicais. O sistema BING apresentou resultados confiáveis e rápidos para a estimativa das propriedades elásticas, notadamente a rigidez, em madeira de Copaifera langsdorffii.
\end{abstract}

Palavras-chave: Acústica, vibração transversal, elasticidade, cisalhamento, rigidez.

\section{INTRODUCTION}

Copaiba (Copaifera langsdorffii Desf.) is a species belonging to the family Leguminosae-Caesalpinoideae which provides moderately dense timber $\left(\sim 700 \mathrm{~kg} \mathrm{~m}^{-3}\right)$ and has good durability under natural conditions. For this reason, Copaiba wood has been recommended for use in building construction, furniture making and lathed parts. Therefore, investigating the elastic properties of this wood species is critical to defining its applications in a way that is suitable and safe.
The mechanical properties of a wood species indicate its capability to withstand efforts and are usually gauged by its strength and stiffness against external forces. The use of a wood species for building construction and structures is conditional on its stiffness properties, given by the modulus of elasticity (MADSEN, 1992). And for this reason, stiffness is one of the most commonly studied mechanical wood properties.

Classic testing determines the static modulus of elasticity (E) using a universal testing machine. As a rule, the static bending test method is performed in expensive

\footnotetext{
${ }^{1}$ Mathematician, MSc in Administration - Instituto Federal de Educação, Ciências e Tecnologia do Sul de Minas Gerais - 37750-000 - Machado, MG, Brasil - edson.rubens@bol.com.br

${ }^{2}$ Forest Engineer, PhD in Tree Biomechanics - Departamento de Ciências Florestais - Universidade Federal de Lavras/UFLA - Campus Universitário - Cx. P. 3037 -37200-000 - Lavras, MG, Brasil - paulohein@dcf.ufla.br

${ }^{3} \mathrm{MSc}$ in Agricultural Engineering - Departamento de Engenharia - Universidade Federal de Lavras/UFLA - Campus Universitário - Cx. P. 3037 37200-000 - Lavras, MG, Brasil - tome@deg.ufla.br

${ }^{4}$ Electrical Engineering, PhD in Agricultural Engineering - Departamento de Engenharia - Universidade Federal de Lavras/UFLA - Campus Universitário - Cx. P. 3037 - 37200-000 - Lavras, MG, Brasil - rabelo@deg.ufla.br
}

Cerne, Lavras, v. 18, n. 1, p. 41-47, jan./mar. 2012 
equipment that demand high maintenance costs, requiring an average 5 to 15 minutes per sample depending on the species and test conditions being used. Therefore, searching for faster, safer alternative methods for determining elastic mechanical properties takes on critical importance within the context of wood science and technology.

Several methods exist which are categorized as nondestructive for determining the modulus of elasticity of various materials. In wood, the most commonly used nondestructive methods for assessing physical, mechanical and elastic properties are based on ultrasound (BALLARIN; NOGUEIRA, 2005; BUCUR, 1984), stress waves (ROSS, 1985), transverse vibration (MURPHY, 1997) and, more recently, near-infrared spectroscopy (SCHIMLECK et al., 2001). According to Bucur (1995), nondestructive methods are also capable of detecting defects in the manufacturing process of plastics, steel and ceramics, which are homogeneous, isotropic materials. In wood, defects occur naturally and can be detected by these methods with reasonable accuracy.

Analysis of transverse vibrations, or resonance, has been identified as the simplest, most inexpensive and effective method of characterizing elastic properties of wood (BRANCHERIAU; BAILLĖRES, 2002). In it, the natural vibration frequency of a material is correlated with its stiffness against bending or compression. This analytical technique has been well described in literature (CALIL JUNIOR; MINÁ, 2003; TARGA et al., 2005) and has been used in the timber industry for the purpose of grading materials. Several studies have demonstrated a strong linear correlation between the dynamic modulus and the static modulus of elasticity as measured in various wood species (BALLARIN et al., 2002; BRANCHERIAU; BAILLÈRES, 2002; CALIL JUNIOR; MINÁ, 2003; GREEN et al., 2004; TARGA et al., 2005; WANG et al., 2001). In addition to industrial applications, vibrational properties can be also used, for instance, for assessing wood quality and potential for the manufacture of musical instruments (OBATAYA et al., 2000).

The objective of this study was thus to evaluate the dynamic elastic properties of wood from Copaifera langsdorffii Desf. by using resonance analysis.

\section{MATERIAL AND METHODS}

\subsection{Sampling}

Wood samples of Copaiba (Copaifera langsdorffii Desf.) were obtained from the campus of Universidade Federal de Lavras, southern Minas Gerais state. The site $\left(21^{\circ} 14^{\prime} \mathrm{S}\right.$ and $45^{\circ} 00^{\prime} \mathrm{W}$ ) is located at an average altitude of 900 meters, lying in a transition zone between the Cerrado and Atlantic Rainforest biomes, and the local climate falls under the $\mathrm{Cwb}$ category according to Köppen classification (PEEL et al., 2007). Twenty-nine samples were cut from a central board one meter in length which had been taken from the trunk base. The defect-free specimens used in bending tests were $300 \times 20 \times 20 \mathrm{~mm}$ in size and had well defined tangential and radial surfaces. It was not possible to determine tree age.

\subsection{Static bending}

The modulus of elasticity (E) was determined by means of a bending test procedure following standard D 14394 (Standard Methods of Testing Small Clear Specimens of Timber) as set out by the American Society for Testing and Materials - ASTM (1997). Tests were performed in a universal testing machine (EMIC DL - $30 \mathrm{kN}$ model, EMIC Equipamentos e Sistemas de Ensaio LTDA).

\subsection{Transverse vibration}

The transverse vibration of wood specimens was evaluated in time and frequency domain by a BING system (Beam Identification by Nondestructive Grading, http://www.xylo-metry.org), as illustrated in Figure 1. The samples were placed in elastic supports in order to generate free vibrations. Vibration is produced by lightly taping a wood-tipped hammer on one end of the specimen. Input and output signals were transmitted using a low-pass filter and a data acquisition card coupled to a computer and then recorded as described by Brancheriau and Baillères (2003).

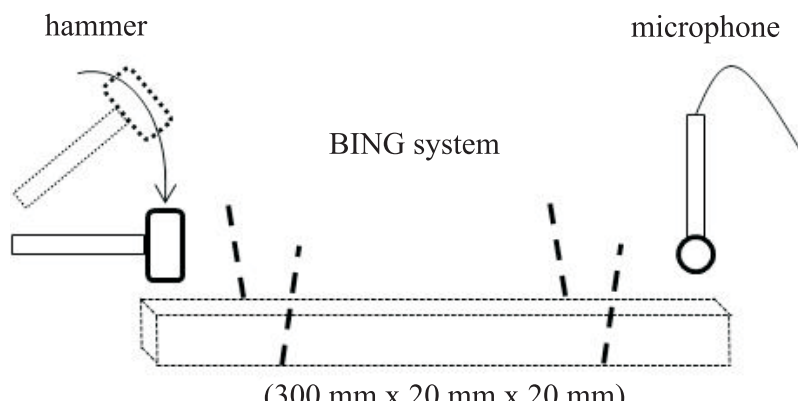

Figure 1 - Experimental device used for measuring time and frequency of transverse vibration in wood samples through the BING system.

Figura 1 - Dispositivo experimental usado para medição do tempo e da frequência de vibração transversal das amostras de madeira por meio do sistema BING.

Cerne, Lavras, v. 18, n. 1, p. 41-47, jan./mar. 2012 
Spectral signal analysis and selection of individual vibration frequency peaks were performed using the software $B I N G \AA$ version 9.1.3. The signal sampling frequency was $39,062 \mathrm{~Hz}$ with spectral acquisition of 32,768 points.

\subsection{Estimation of dynamic parameters}

The theoretical model used for describing the resonance of a prismatic, uniform, freely vibrating specimen was proposed by Timoshenko (1921) as follows:

$E_{X} I_{G z} \frac{\partial^{4} v}{\partial x^{4}}-D I_{G z}\left(1+\frac{E_{X}}{K G_{X Y}}\right) \frac{\partial^{4} v}{\partial x^{2} \partial t^{2}}+\frac{D^{2} I_{G z}}{K G_{X Y}} \frac{\partial^{4} v}{\partial t^{4}}+$

$D A \frac{\partial^{2} v}{\partial t^{2}}=0$

where $\mathrm{E}_{X}$ is modulus of elasticity (or Young's modulus); $\mathrm{I}_{G z}$ is moment of inertia, $v$ is transverse movement; $x$ is distance along the beam axis; $D$ is density; $\mathrm{K}$ is a constant that depends on the geometry of the section (for a rectangular section, $\mathrm{K}=5 / 6$ ); $G_{X Y}$ is shear modulus; $t$ is time and $A$ is the cross-sectional area of the beam. Using the solution proposed by Bordonné (1989) for this differential equation, the effect of shear is taken into account while the effects of support are ignored. The modulus of elasticity $\left(\mathrm{E}_{\mathrm{X}}\right)$ and shear modulus $\left(\mathrm{G}_{\mathrm{XY}}\right)$ can be calculated as follows:

$\frac{E_{X}}{D}-\frac{E_{X}}{K G_{X Y}}\left[Q F_{2}(m) 4 \pi^{2} \frac{A L^{4}}{I_{G z}} \frac{f_{n}^{2}}{P_{n}}\right]=4 \pi^{2} \frac{A L^{4}}{I_{G z}} \frac{f_{n}^{2}}{P_{n}}[1+$

$\left.Q F_{1}(m)\right]$

where $f_{\mathrm{i}}$ is the ith resonance frequency, $\mathrm{P}$ is Bernoulli's solution ( $\mathrm{n}$ rank) and $\mathrm{L}$ is prism length. The calculation of parameters $\mathrm{m}, \mathrm{P}_{\mathrm{n}}, \mathrm{Q}, \mathrm{F}_{1}(\mathrm{~m})$ and $\mathrm{F}_{2}(\mathrm{~m})$ and $\theta$ is described in Hein et al. (2012). Internal damping (tg $\delta$ ) (or friction) was calculated according to the equation provided by Brancheriau et al. (2006):

$\operatorname{tg} \delta=\frac{\alpha_{1}}{\pi f_{1}}$

where $f_{1}$ is first resonance frequency and $\alpha_{1}$ is temporal damping associated with $f_{1}$. Only the first frequency was computed because of its high energy. A detailed discussion on different theoretical models about the movement, approximate solutions and respective hypotheses concerning longitudinal and transverse vibrations, as well as the effects of the elastic support used in the BING procedure, is provided in Brancheriau and Baillères (2002).

The samples were kept in a temperature-controlled room at $21^{\circ} \mathrm{C}$ and $65 \%$ relative humidity. Under these conditions, the moisture of wood samples stabilized at $14 \%$. The apparent density (D) of stabilized specimens was given as the ratio of specimen size, as measured with a caliper, to specimen mass, as measured with a scale accurate to 0.001 grams, immediately before the dynamic test. The specific modulus (E') was given as the ratio of dynamic modulus of elasticity to apparent density.

Correlations between properties, analyses of variance, linear regressions and prediction errors were determined using the software Statgraphics Plus for Windows v.2.1 (Statistical Graphics Corp., Maryland, USA).

\section{RESULTS AND DISCUSSION}

\subsection{Dynamic and static determination of elastic parameters}

Table 1 provides results of elastic parameters against static bending as measured by a universal testing machine, and against dynamic bending as measured by transverse vibration, in wood specimens of Copaifera langsdorffii.

With moisture content stabilized at $14 \%$, the apparent density of specimens ranged from 709 to $914 \mathrm{~kg} \mathrm{~m}^{-3}$. Stiffness, as indicated by the modulus of elasticity, had wider variation: $20 \%$ under static bending and as measured by the testing machine, and $22.6 \%$ under dynamic bending. The mean dynamic modulus of elasticity was higher than the static value, an expected pattern also reported by other authors (BURDZIK; NKWERA, 2002; ILIC, 2001; TARGA et al., 2005). Shear modulus $(G)$ had the greatest variation among samples. Due to the difficulty in obtaining accurate measurements of internal damping ( $\operatorname{tg} \delta$ ) (or friction), this property is rarely reported in literature. The variation $(16 \%<\mathrm{CV}<44 \%)$ found in the viscoelastic properties of these wood specimens is considered normal. Trees are subjected to many influences that include moisture, soil conditions and tree spacing, producing wood with widely varying characteristics.

Cerne, Lavras, v. 18, n. 1, p. 41-47, jan./mar. 2012 
Table 1 - Descriptive statistics of results of elasticity after subjection to static bending $(\mathrm{E})$ and dynamic bending $\left(\mathrm{E}_{\mathrm{d}}\right)$, specific modulus (E'), internal damping ( $\operatorname{tg} \delta$ ), shear modulus $(\mathrm{G})$ and apparent density (D), in wood specimens of Copaifera langsdorffii.

Tabela 1 - Estatística descritiva dos resultados de elasticidade em ensaio de flexão estática (E) e dinâmica (E $\left.E_{d}\right)$, módulo específico $\left(E^{\prime}\right)$, amortecimento interno ( $\left.\operatorname{tg} \delta\right)$, módulo de cisalhamento $(G)$ e densidade aparente $(D)$ para a madeira de Copaifera langsdorffii.

\begin{tabular}{lcccccc}
\hline & $\mathrm{E}(\mathrm{MPa})$ & $\mathrm{E}_{\mathrm{d}}(\mathrm{MPa})$ & $\mathrm{E}^{\prime}\left(\mathrm{MPa} \mathrm{m}^{3} \mathrm{~kg}^{-1}\right)$ & $\operatorname{tg} \delta\left(10^{3}\right)$ & $\mathrm{G}(\mathrm{MPa})$ & $\mathrm{D}\left(\mathrm{m}^{3} \mathrm{~kg}^{-1}\right)$ \\
\hline Mean & 11,359 & 12,015 & 14.17 & 11.89 & 2,217 & 844 \\
Stand. deviation & 1,825 & 2,355 & 2.21 & 2.03 & 960 & 58 \\
Minimum & 6,875 & 7,210 & 9.28 & 7.18 & 1,195 & 709 \\
Maximum & 14,700 & 17,360 & 19.56 & 15.40 & 6,015 & 915 \\
$\mathrm{CV}(\%)$ & 16.1 & 19.6 & 15.6 & 17.1 & 43.3 & 6.9 \\
$\mathrm{~N}$ & 29 & 29 & 29 & 29 & 29 & 29 \\
\hline
\end{tabular}

\subsection{Correlation between physical and elastic parameters in Copaiba wood}

Table 2 illustrates the correlation between dynamic properties in specimens of Copaifera langsdorffii. Elastic constants measured by destructive (E) and nondestructive $\left(\mathrm{E}_{\mathrm{d}}\right)$ testing had a correlation of 0.94 ; these elastic constants had a less significant correlation with apparent density (D) $(0.72<\mathrm{R}<0.67)$. Shear modulus $(\mathrm{G})$ had low significance correlations with other properties. The correlation between internal damping $(\operatorname{tg} \delta$ ) and specific modulus (E') was -0.61 .

Table 2 - Correlation between apparent density (D), elasticity under static bending $(\mathrm{E})$ and dynamic bending $\left(\mathrm{E}_{\mathrm{d}}\right)$ and shear $(\mathrm{G})$ in wood specimens of Copaifera langsdorffii.

Tabela 2 - Correlação entre a densidade aparente (D), elasticidade em ensaio de flexão estática $(E)$ e dinâmica $\left(E_{d}\right)$ e cisalhamento $(G)$ para a madeira de Copaifera langsdorffii.

\begin{tabular}{ccccccc}
\hline & $E$ & $E_{d}$ & $E^{\prime}$ & $\operatorname{tg} \delta$ & $G$ & $D$ \\
\hline$E$ & 1 & & & & & \\
$E_{d}$ & 0.937 & 1 & & & & \\
$E^{\prime}$ & 0.907 & 0.955 & 1 & & & \\
$\operatorname{tg} \delta$ & -0.591 & -0.504 & -0.617 & 1 & & \\
$G$ & -0.199 & -0.139 & -0.080 & 0.040 & 1 & \\
$D$ & 0.670 & 0.721 & 0.487 & -0.058 & -0.200 & 1 \\
\hline
\end{tabular}

Figure 2 illustrates the correlation between the destructive and the nondestructive method for determination of stiffness in wood specimens of Copaifera langsdorffii. Results are consistent with correlations found in other studies between dynamic and static moduli of elasticity, applying the same methodology (BRANCHERIAU;

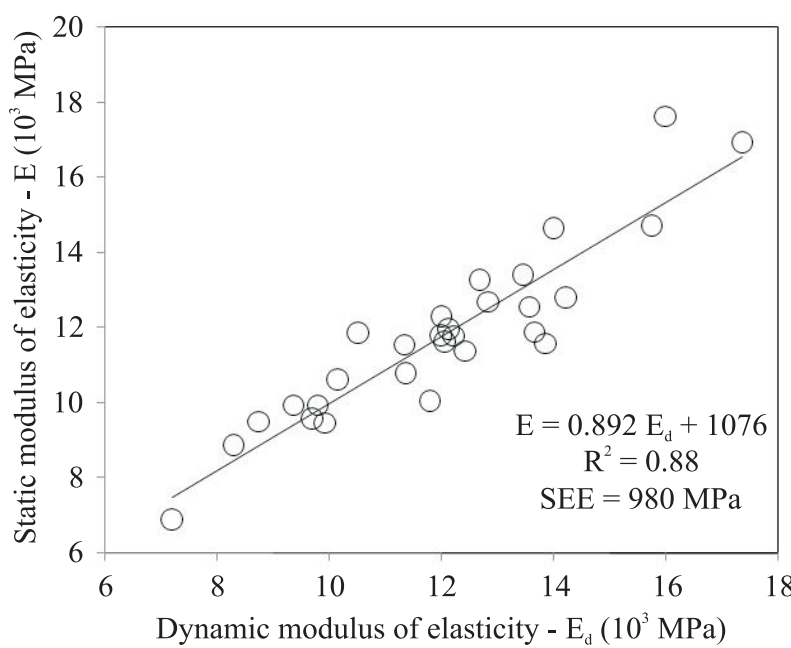

Figure 2 - Correlation between the static modulus of elasticity (E) as measured by a universal testing machine and the dynamic modulus of elasticity $\left(\mathrm{E}_{\mathrm{d}}\right)$ as measured by the BING system.

Figura 2 - Correlação entre módulo de elasticidade estático ( $E$ - medido pela máquina universal de ensaios) e dinâmico ( $E_{d}$ - medido pelo sistema BING).

BAILLÈRES, 2003; CALIL JUNIOR; MINÁ, 2003; HAINES et al., 1996; ILIC, 2003; OHSAKI et al., 2007; TARGA et al., 2005), yet using other wood species. Ilic (2001), for instance, evaluated Eucalyptus wood and found a strong correlation $(\mathrm{r}=0.99)$ between the dynamic modulus and the static modulus of elasticity. Again, this author did not find significant correlations between shear modulus (G) and elasticity. Targa et al. (2005) evaluated three Eucalyptus species and reported correlations between the dynamic and the static moduli of elasticity, with an $\mathrm{R}^{2}$ of 0.87 for E. citriodora and E. grandis; and 0.76 for $E$. saligna. Spycher et al. (2008) evaluated wood samples of

Cerne, Lavras, v. 18, n. 1, p. 41-47, jan./mar. 2012 
the genera Picea and Acer and found good correlations between the two gauging methods, with deviations of $0.1 \%$ to $0.6 \%$ between the dynamic modulus and the static modulus of elasticity. The consistency between these previous studies and results found in this work (Table 2) indicates that the BING system is sufficiently reliable and accurate for evaluating elastic properties in wood.

Table 3 provides the analysis of variance of the linear regression model to describe the correlation of $\mathrm{E}$ with $\mathrm{E}_{\mathrm{d}}$. The P-value in Table 3 being less than 0.01 is an indication of a statistically significant correlation between $E$ and $E_{d}$ at the $99 \%$ confidence level. The $\mathrm{R}^{2}$ statistic indicates that the model fit explains $88 \%$ of the variability in static elasticity. The correlation coefficient was 0.94 (Table 2), indicating a strong correlation between the methods of analysis. The standard error of estimate shows a standard deviation of residuals of $980 \mathrm{MPa}$. This value could be used for setting prediction thresholds in future elasticity estimates based on transverse vibration.

Table 3 - Analysis of variance of the regression describing the E $x E_{\mathrm{d}}$ correlation.

Tabela 3 - Análise de variância da regressão que descreve a relação entre $E$ e $E_{d}$.

\begin{tabular}{lccccc}
\hline Source & SS & DF & MS & Calc-F & P-value \\
\hline Model & $1.231 \times 10^{8}$ & 01 & $1.231 \times 10^{8}$ & 142.5 & 0.000 \\
Residual & $2.159 \times 10^{7}$ & 25 & 863.972 & & \\
Total (corr.) & $1.447 \times 10^{8}$ & 26 & & & \\
\hline
\end{tabular}

SS: sum of squares; DF: degrees of freedom; MS: mean square; Calc-F: calculated F; P-Value: comparison value with an $\alpha$ significance level.

\subsection{Viscoelasticity of the wood specimens}

Among other purposes, viscoelastic properties are used for evaluating wood quality prior to the manufacture of musical instruments (OBATAYA et al., 2000). According to Ono and Norimoto (1984), woods with a high specific modulus and low internal damping are suitable for musical instruments such as pianos and violins. For this reason, the few existing studies exploring this issue were performed using hardwood. Another limiting factor for studying viscoelastic properties is the difficulty found in accurately measuring internal damping. Hence the correlation between internal damping and specific modulus (ratio of dynamic modulus of elasticity to apparent density) in tropical woods being rarely reported in literature.
In this work, an approximately linear correlation was found between the specific modulus and the internal damping (Figure 3), indicating that wood from Copaifera langsdorffii (or at least part of it) has interesting acoustic properties for the manufacture of musical instruments. The E' $x \operatorname{tg} \delta$ correlation for Copaifera langsdorffii was found to be very similar to that reported by Ono and Norimoto (1984), who evaluated this correlation in 30 types of hardwood. Obataya et al. (2000) found a similar E' $x \operatorname{tg} \delta$ correlation for wood from Picea sitchensis. According to Ono and Norimoto (1985), the modulus of elasticity and internal damping of a wood specimen are determined to a large degree by the angle of microfibrils in the $\mathrm{S}_{2}$ layer of its fibers.

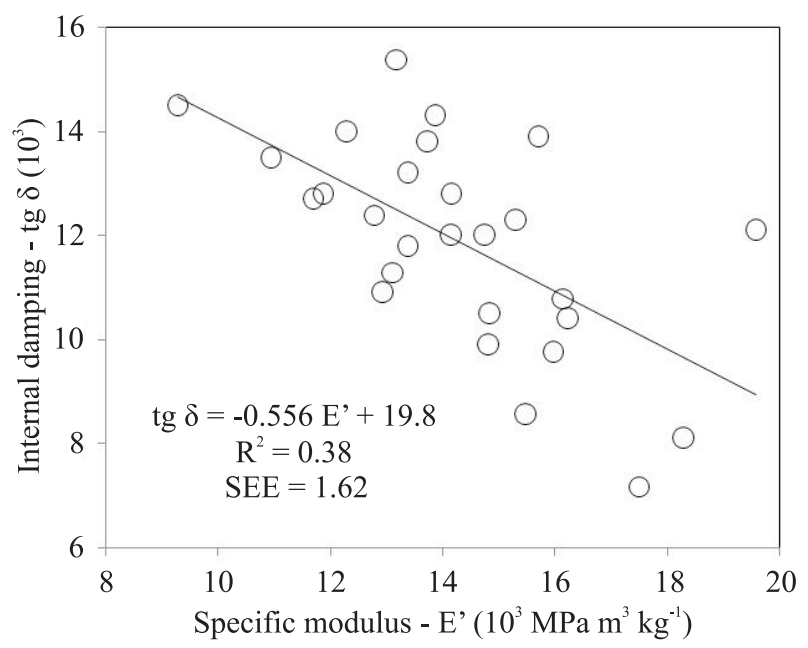

Figure 3 - Correlation between specific modulus (E') and internal damping in wood specimens of Copaifera langsdorffii.

Figura 3 - Correlação entre módulo específico ( $\left.E^{\prime}\right) e$ amortecimento interno das amostras do lenho de Copaifera langsdorffii.

\section{CONCLUSIONS}

Despite the limited number of samples investigated in this work, results revealed that the BING system was capable of determining the stiffness as well as the shear modulus and internal damping of wood from Copaifera langsdorffii. A strong correlation was found $\left(\mathrm{R}^{2}=0.88\right)$ between the modulus of elasticity determined by transverse vibration and the value determined by the universal testing machine. A moderate correlation was found (0.69) between the $E_{d}$ and the apparent density of the wood specimens. The shear modulus was negatively correlated with density and with elastic constants, yet not significantly.

Cerne, Lavras, v. 18, n. 1, p. 41-47, jan./mar. 2012 
The specific modulus, which is the ratio of stiffness to density, was negatively and linearly correlated with internal damping (or friction). This viscoelastic correlation is rarely reported in literature and indicates, for instance, the quality of the wood in question for manufacture of musical instruments. However, further studies are required in order to investigate the quality of acoustic properties in Copaiba wood. The resonance analysis performed by the BING system provided fast, reliable results for the estimation of elastic properties, particularly stiffness, in wood of Copaifera langsdorffii.

\section{ACKNOWLEDGMENTS}

The authors wish to thank the Departamento de Ciências Florestais, Universidade Federal de Lavras, for providing equipment and measuring instruments with which to carry out this study; the UR40 research team from CIRAD (Centre de coopération internationale en recherche agronomique pour le développement - Montpellier, France) for their technical support and for providing equipment and software in order to use the BING system; CNPq (Process 200970/2008-9) and CAPES for providing scholarships; and Instituto Federal Sul de Minas (IFSULDEMINAS) Campus Machado.

\section{REFERENCES}

AMERICAN SOCIETY FOR TESTING AND MATERIALS. D 143-94: standard methods of testing small, clear specimens of timber. In: Annual book of ASTM standards. Denvers, 1997. p. 23-53.

BALLARIN, A. W.; NOGUEIRA, M. Determinação do módulo de elasticidade da madeira juvenil e adulta de Pinus taeda por ultra-som. Engenharia Agrícola, Jaboticabal, v. 25, n. 1, p. 19-28, jan./abr. 2005.

BALLARIN, A. W.; TARGA, L. A.; PALMA, H. A. L. Ensaios não-destrutivos de vibração transversal na avaliação do módulo de elasticidade de madeiras de reflorestamento. In: ENCONTRO BRASILEIRO EM MADEIRAS E EM ESTRUTURAS DE MADEIRA, 8., 2002, Uberlândia. Anais... Uberlândia: UFU, 2002. CD-ROM.

BORDONNÉ, P. A. Module dynamique et frottement intérieur dans le bois, mesures sur poutres flottantes en vibrations naturelles. Lorraine: Institut National Polytechnique de Lorraine, 1989. 109 p.

Cerne, Lavras, v. 18, n. 1, p. 41-47, jan./mar. 2012
BRANCHERIAU, L.; BAILLÈRES, H. Natural vibration analysis of clear wooden beams: a theoretical review. Wood Science and Technology, Berlin, v. 36, p. 347-365, 2002.

BRANCHERIAU, L.; BAILLÈRES, H. Use of the partial least squares method with acoustic vibration spectra as a new grading technique for structural timber. Holzforschung, Berlin, v. 57, n. 6, p. 644-652, 2003.

BRANCHERIAU, L.; BAILLÈRES, H.; DÉTIENNE, P.; GRIL, J.; KRONLAND-MARTINET, R. Key signal and wood anatomy parameters related to the acoustic quality of wood for xylophone-type percussion instruments. Journal of Wood Science, Kyoto, v. 52, n. 3, p. 270-274, 2006.

BUCUR, V. Acoustics of wood. New York: CRC, 1995. 284 p.

BUCUR, V. Ondes ultrasonores dans le bois: caracterisation mécanique et qualité de certaines essences de bois. 1984. 188 f. Thèse (Doctorat en Génie Mécanique) - Institut Supérieur des materiaux et de la Construction Mécanique, Saint-Quen, 1984.

BURDZIK, W. M. G.; NKWERA, P. D. Transverse vibration tests for prediction of stiffness and strength properties of full size Eucalyptus grandis. Forest Products Journal, Madison, v. 52, n. 6, p. 63-67, 2002.

CALIL JÚNIOR, C.; MINÁ, A. J. S. Vibração transversal: um método eficiente para classificação de peças estruturais de madeira. Revista Brasileira de Engenharia Agrícola e Ambiental, Campina Grande, v. 7, n. 2, p. 335-338, 2003.

GREEN, D. W.; GORRNAN, T. M.; EVANS, J. W.; MURPHY, J. F. Improved grading system for structural logs for log homes. Forest Products Journal, Madison, v. 54, n. 9 , p. 59-62, 2004.

HAINES, D. W.; LEBAN, J. M.; HERBE, C. Determination of young's modulus for spruce, fir and isotropic materials by the resonance flexure method with comparisons to static flexure and other dynamic methods. Wood Science and Technology, Berlin, v. 30, n. 4, p. 253-263, 1996.

HEIN, P. R. G.; LIMA, J. T.; GRIL, J.; ROSADO, A. M.; BRANCHERIAU, L. Resonance of structural timbers indicates the stiffness even of small specimens of Eucalyptus from plantations. Wood Science and Technology, Berlin, 2012. In press. 
ILIC, J. Dynamic MOE of 55 species using small wood beams. Holz als Roh- und Werkstoff, Berlin, v. 61, p. 167$172,2003$.

ILIC, J. Relationship among the dynamic and static elastic properties of air-dry Eucalyptus delegatensis R. Baker. Holz als Roh- und Werkstoff, Berlin, v. 59, p. 169-175, 2001.

MADSEN, B. Structural behaviour of timber. Vancouver: Timber Engeneering, 1992.

MURPHY, J. F. Transverse vibration of a simply supported beam with symmetric overhang of arbitrary length. Journal of Testing and Evaluation, Madison, v. 25, n. 5, p. 522-524, 1997.

OBATAYA, E.; ONO, T.; NORIMOTO, M. Vibrational properties of wood along the grain. Journal of Materials Science, Berlin, v. 35, n. 12, p. 2993-3001, 2000.

OHSAKI, H.; KUBOJIMA, Y.; TONOSAKI, M.; OHTA, M. Vibrational properties of wetwood of todomatsu (Abies sachalinensis) at high temperature. Journal of Wood Science, Kyoto, v. 53, p. 134-138, 2007.

ONO, T.; NORIMOTO, M. Anisotropy of dynamic Young's modulus and internal friction in wood. Japanese Journal of Applied Physics, Tokyo, v. 24, n. 8, p. 960-964, 1985.

ONO, T.; NORIMOTO, M. On physical criteria for the selection of wood for soundboards of musical instruments. Rheologica Acta, Prague, v. 23, n. 6, p. 652-656, 1984.

PEEL, M. C.; FINLAYSON, B. L.; MCMAHON, T. A. Updated world map of the Köppen-Geiger climate classification. Hydrology Earth System Science, Berlin, v. 11, p. 1633-1644, 2007.

ROSS, R. J. Stress wave propagation in wood products. In: NON DESTRUCTIVE TESTING OF WOOD SYMPOSIUM, 5., 1985, Pullman. Proceedings... Pullman: Washington State University, 1985. p. 291-318.

SCHIMLECK, L. R.; EVANS, R.; ILIC, J. Estimation of Eucalyptus delegatensis wood properties by Near Infrared Spectroscopy. Canadian Journal of Forest Research, New Westminster, v. 31, p. 1671-1675, 2001.

SPYCHER, M.; SCHWARZE, F. W. M. R.; STEIGER, R. Assessment of resonance wood quality by comparing its physical and histological properties. Wood Science and Technology, Berlin, v. 42, n. 4, p. 325-342, 2008.

TARGA, L. A.; BALLARIN, A. W.; BIAGGIONI, M. A. M. Avaliação do módulo de elasticidade da madeira com uso de método não-destrutivo de vibração transversal. Engenharia Agrícola, Jaboticabal, v. 25, n. 2, p. 291-299, maio/ago. 2005.

TIMOSHENKO, S. On the correction for shear of the differential equation for transverse vibrations of prismatic bars. Philosophical Magazine and Journal of Science XLI, New York, v. 6, p. 744-746, 1921.

WANG, X.; ROSS, R. J.; MATTSON, J. A.; ERICKSON, J. R.; FORSMAN, J. W.; GESKE, E. A.; WEHR, M. A. Several nondestructive evaluation techniques for assessing stiffnes and MOE of small-diameter logs. Madison: USDA, 2001. (General Technical Report FPL-RP, 600).

Cerne, Lavras, v. 18, n. 1, p. 41-47, jan./mar. 2012 